Results: Overall, 740 and 539 pts were randomised to IV GLM and PBO groups, respectively. The\% of IV GLM vs PBO pts reported the following across studies: infusion reactions ( 2.8 vs 0.2 ); SAEs ( 3.8 vs 2.4 ); infections ( 23.8 vs 17.3 ); serious infections (0.8 vs 0.4$)$ and malignancies ( 0.1 vs 0.4$)$. No deaths occurred in IV GLM group through wk24. Pts on IV GLM $(n=574)$ vs PBO $(n=391)$ w/concomitant MTX had similar proportions of serious infections ( 0.9 vs. 0.6$)$. In IV GLM ( $n=349)$ vs PBO $(n=224)$ pts who received CS, serious infections were $1.1 \%$ vs $0.9 \%$; in pts who did not receive CS, serious infections were $0.5 \%$ vs $0 \%$. In IV GLM pts w/ normal ALT at baseline, $30 \%$ had postbaseline ALT elevation w/concomitant MTX vs $28 \%$ w/o. CS use had inconsistent effect on ALT elevations. Overall incidence of ADAs via drug tolerant assay was $20 \%$ (19\% w/ MTX and $25 \% \mathrm{w} / \mathrm{o}$ MTX) through wk20 across RA, PsA and AS studies.

\begin{tabular}{|c|c|c|c|c|c|c|c|c|}
\hline & \multicolumn{2}{|c|}{ RA } & \multicolumn{2}{|c|}{ PsA } & \multicolumn{2}{|c|}{ AS } & \multicolumn{2}{|c|}{ ALL } \\
\hline & $\begin{array}{l}\text { IV } \\
\text { GLM }\end{array}$ & PBO & $\begin{array}{l}\text { IV } \\
\text { GLM }\end{array}$ & PBO & $\begin{array}{l}\text { IV } \\
\text { GLM }\end{array}$ & PBO & $\begin{array}{c}\text { IV } \\
\text { GLM }\end{array}$ & PBO \\
\hline Treated Pts & 395 & 197 & 240 & 239 & 105 & 103 & 740 & 539 \\
\hline $\begin{array}{l}\text { Age in years, Mean } \\
\text { (Range) }\end{array}$ & $\begin{array}{r}51.9 \\
\left({ }^{18-83}\right.\end{array}$ & $\begin{array}{r}51.4 \\
\left({ }^{19-78}\right.\end{array}$ & $\begin{array}{r}45.7 \\
\left({ }^{19-69}\right.\end{array}$ & $\begin{array}{r}46.7 \\
\left({ }^{18-79}\right.\end{array}$ & $\begin{array}{r}38.4 \\
\left({ }^{19-64}\right.\end{array}$ & $\begin{array}{r}39.2 \\
(20-67\end{array}$ & & \\
\hline $\begin{array}{l}\text { Disease Duration in } \\
\text { Years, Mean (SD) }\end{array}$ & $\begin{array}{c}6.9 \\
(7.00)\end{array}$ & $\begin{array}{c}7.0 \\
(7.24)\end{array}$ & $\begin{array}{c}6.2 \\
(6.03)\end{array}$ & $\begin{array}{c}5.3 \\
(5.92)\end{array}$ & $\begin{array}{c}5.6 \\
(6.57)\end{array}$ & $\begin{array}{c}5.5 \\
(5.93)\end{array}$ & & \\
\hline $\begin{array}{l}\text { Avg duration of } \\
\text { follow-up (wks) }\end{array}$ & 23.6 & 20.9 & 23.9 & 23.2 & 16.1 & 16.0 & 22.6 & 21.0 \\
\hline $\begin{array}{l}\text { Pts } w / \geq 1 \text { infusion } \\
\text { reaction, } \\
n(\%)\end{array}$ & $\begin{array}{c}14 \\
(3.5)\end{array}$ & $1(0.5)$ & $4(1.7)$ & 0 & $3(2.9)$ & 0 & $\begin{array}{c}21 \\
(2.8)\end{array}$ & $1(0.2)$ \\
\hline $\begin{array}{l}\text { Pts w/ } \geq 1 \text { SAE, } \\
\mathrm{n}(\%)\end{array}$ & $\begin{array}{c}19 \\
(4.8)\end{array}$ & $5(2.5)$ & $7(2.9)$ & $8(3.3)$ & $2(1.9)$ & 0 & $\begin{array}{c}28 \\
(3.8)\end{array}$ & $\begin{array}{c}13 \\
(2.4)\end{array}$ \\
\hline $\begin{array}{l}\text { Pts } w / \geq 1 \text { infection, } n \\
(\%)\end{array}$ & $\begin{array}{c}119 \\
(30.1)\end{array}$ & $\begin{array}{c}48 \\
(24.4)\end{array}$ & $\begin{array}{c}45 \\
(18.8)\end{array}$ & $\begin{array}{c}37 \\
(15.5)\end{array}$ & $\begin{array}{c}12 \\
(11.4)\end{array}$ & $8(7.8)$ & $\begin{array}{c}176 \\
(23.8)\end{array}$ & $\begin{array}{c}93 \\
(17.3)\end{array}$ \\
\hline $\begin{array}{l}\text { Pts } w / \geq 1 \text { serious } \\
\text { infection, } n(\%)\end{array}$ & $4(1.0)$ & 0 & $1(0.4)$ & $2(0.8)$ & $1(1.0)$ & 0 & $6(0.8)$ & $2(0.4)$ \\
\hline $\begin{array}{l}\text { Pts } w / \geq 1 \text { malignancy, } \\
n(\%)\end{array}$ & $1(0.3)$ & 0 & 0 & $2(0.8)$ & 0 & 0 & $1(0.1)$ & $2(0.4)$ \\
\hline Deaths, n (\%) & 0 & $1(0.5)$ & 0 & $2(0.8)$ & 0 & 0 & 0 & $3(0.6)$ \\
\hline$\%$ ADA positive* & 21 & & 20 & & 19 & & 20 & \\
\hline
\end{tabular}

${ }^{*}$ w/drug tolerant assay

Conclusions: IV GLM demonstrates the expected safety profile across RA, PSA and AS clinical trials in the PBO-controlled period. Differences between studies may be related to age, use of concomitant medications and disease indication. Disclosure of Interest: M. Husni: None declared, S. Schwartzman: None declared, A. Deodhar: None declared, S. Kafka Employee of: Janssen Scientific Affairs, LLC, S. Chakravarty: None declared, E. Hsia: None declared, D. Harrison: None declared, J. Leu: None declared, Y. Zhou: None declared, K. Lo: None declared, A. Kavanaugh: None declared

DOI: 10.1136/annrheumdis-2018-eular.5425

\section{FRI0129 SWITCH BETWEEN REFERENCE ETANERCEPT (ETN) AND GP2015, AN ETANERCEPT BIOSIMILAR, DID NOT IMPACT EFFICACY AND SAFETY IN PATIENTS WITH MODERATE-TO-SEVERE RHEUMATOID ARTHRITIS: 48- WEEK RESULTS FROM THE PHASE 3 EQUIRA STUDY}

M. Matucci-Cerinic ${ }^{1}$, H. Schulze-Koops ${ }^{2}$, M. Buch ${ }^{3}$, A. Kavanaugh ${ }^{4}$, Y. Allanore ${ }^{5}$, E.J. Kucharz ${ }^{6}$, G. Babic ${ }^{7} .{ }^{1}$ University of Florence, Florence, Italy; ${ }^{2}$ LudwigMaximilians-University, Munich, Germany; ${ }^{3}$ University of Leeds, Leeds, UK; ${ }^{4}$ UC San Diego School of Medicine, La Jolla, California, USA; ${ }^{5}$ Cochin Hospital, Paris Descartes University, Paris, France; ${ }^{6}$ Medical University of Silesia, Katowice, Poland; ${ }^{7}$ Hexal AG, a Sandoz company, Holzkirchen, Germany

Background: GP2015 is an etanercept biosimilar. It has shown an equivalent efficacy, and comparable safety and immunogenicity to ETN in patients with chronic plaque-type psoriasis. ${ }^{1}$

Objectives: To compare the efficacy and safety of GP2015 versus ETN in patients with moderate-to-severe rheumatoid arthritis (RA) and evaluate the effects of switching from ETN to GP2015.

Methods: EQUIRA was a 48 week, randomised, double-blind, Phase 3 study. The primary endpoint was equivalent change from baseline (BL) in DAS28-CRP at Week 24. Patients $\geq 18$ years with active RA ACR 1987 or ACR/ $/{ }^{\text {EULAR }} 2010$ criteria for $>6$ months before $B L$ and active disease defined as DAS28-CRP $>3.2$ and CRP $>5 \mathrm{mg} / \mathrm{L}$ or $\mathrm{ESR} \geq 28 \mathrm{~mm} / \mathrm{h}$ ) and inadequate response to methotrexate (MTX) were randomised $1: 1$ to $50 \mathrm{mg}$ GP2015 or ETN subcutaneously once weekly for 24 weeks (Treatment period 1). Patients with at least moderate EULAR response at Week 24 either continued GP2015 treatment or, in the ETN group, were switched to receive $50 \mathrm{mg}$ GP2015 up to 48 weeks (Treatment period 2 [TP2]). All patients continued to receive concomitant MTX (10-25 mg/week) at a stable dose and folic acid. Efficacy outcome measures included change in DAS28-CRP, EULAR and ACR20/50/70 responses.
Results: Baseline characteristics were comparable between the GP2015 $(n=186)$ and ETN $(n=190)$ groups. The primary endpoint for equivalence was met. $^{2}$ The mean change in DAS28-CRP from BL to Week 48 was comparable between the continued and switched to GP2015 groups (TP2 per-protocol set; figure 1). At Week 48, the EULAR and ACR 20/50/70 response rates were comparable between the two groups (table 1). In TP2, treatment-emergent adverse events (AEs) occurred in $42.9 \%$ vs $38.0 \%$ patients in the continued GP2015 ( $n=175)$ vs the switched $(n=166)$ groups; serious AEs occurred in $2.3 \%$ vs $2.4 \%$ patients (TP2 safety set). Injection site reactions occurred in $6(3.6 \%)$ patients in the switched group but none in the continued GP2015 group. In TP2, 4 (2.4\%) patients in the continued GP2015 group had single-event, very low titer, non-neu tralising antidrug antibodies detected.

Abstract FRI0129 - Table 1. Efficacy response over 48 weeks, TP2 per-protocol set (W=week)

\begin{tabular}{lccc}
\hline Variables & Time & $\begin{array}{c}\text { Continued } \\
\text { GP2015 } \\
\mathbf{n}=148\end{array}$ & $\begin{array}{c}\text { Switched to } \\
\text { GP2015 } \\
\mathbf{n}=131\end{array}$ \\
\hline $\begin{array}{l}\text { EULAR good response, } \mathrm{n}(\%) \\
\text { EULAR moderate response, } \mathrm{n}\end{array}$ & W48 & $80(54.4)$ & $67(51.9)$ \\
$(\%)$ & W48 & $61(41.5)$ & $57(44.2)$ \\
ACR20 response, $\mathrm{n}(\%)$ & W4 & $70(47.9)$ & $70(53.8)$ \\
& W12 & $114(78.1)$ & $100(76.9)$ \\
& W24 & $132(89.8)$ & $122(93.1)$ \\
& W36 & $128(87.7)$ & $114(87.0)$ \\
ACR50 response, $\mathrm{n}(\%)$ & W48 & $131(89.1)$ & $108(82.4)$ \\
& W4 & $19(13.0)$ & $26(20.0)$ \\
& W12 & $48(32.9)$ & $61(46.9)$ \\
& W24 & $93(63.3)$ & $96(73.3)$ \\
ACR70 response, $\mathrm{n}(\%)$ & W36 & $90(61.6)$ & $83(63.4)$ \\
& W48 & $93(63.3)$ & $86(65.6)$ \\
& W4 & $6(4.1)$ & $6(4.6)$ \\
& W12 & $18(12.3)$ & $24(18.5)$ \\
& W24 & $50(34.0)$ & $60(45.8)$ \\
& W36 & $47(32.2)$ & $50(38.2)$ \\
& W48 & $54(36.7)$ & $55(42.0)$ \\
\hline
\end{tabular}

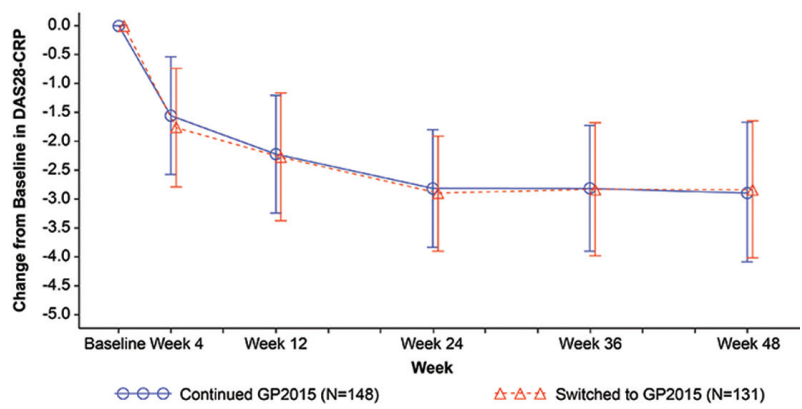

Abstract FRI0129 - Figure 1. Change from Baseline in DAS28-CRP up to Week 48 (TP2 per-protocol set)

Conclusions: The efficacy of GP2015 was comparable to that of ETN. Moreover, the switch from ETN to GP2015 did not impact on efficacy and safety of etanercept in patients with moderate-to-severe RA

\section{REFERENCES}

[1] Griffiths CEM, et al. Br J Dermatol 2017;176:928-38.

[2] Kavanaugh A, et al. Arthritis Rheumatol 2017;69(suppl 10).

Disclosure of Interest: M. Matucci-Cerinic Grant/research support from: Actelion, Beyer, BMS, Chemomab, Inventiva, Pfizer and Sandoz, H. Schulze-Koops: None declared, M. Buch Grant/research support from: Abbvie, AstraZeneca, El Lilly, Pfizer, Roche, Sandoz and UCB, Consultant for: Abbvie, AstraZeneca, Eli Lilly, Pfizer, Roche, Sandoz and UCB, A. Kavanaugh Consultant for: Sandoz, Merck and Boehringer-Ingelheim, Y. Allanore Grant/research support from: Pfizer and Sandoz, Consultant for: Pfizer and Sandoz, E. J. Kucharz Consultant for: AbbVie, Berlin Chemie, Biogen, Celgene, Egis, Eli Lilly Polska, MSD, Novartis, Pfizer, Polpharma, Roche, Sandoz and UCB Biopharma, G. Babic Employee of: Hexal AG

DOI: 10.1136/annrheumdis-2018-eular.1368 